Meta

Journal des traducteurs

Translators' Journal

\title{
Translation, Adaptation, Inscription: Displacing God in Austen's Sense and Sensibility
}

\author{
Alan J. E. Wolf
}

Volume 56, numéro 4, décembre 2011

URI : https://id.erudit.org/iderudit/1011257ar

DOI : https://doi.org/10.7202/1011257ar

Aller au sommaire du numéro

Éditeur(s)

Les Presses de l’Université de Montréal

ISSN

0026-0452 (imprimé)

1492-1421 (numérique)

Découvrir la revue

Citer cet article

Wolf, A. J. E. (2011). Translation, Adaptation, Inscription: Displacing God in Austen's Sense and Sensibility. Meta, 56(4), 861-877.

https://doi.org/10.7202/1011257ar

\section{Résumé de l'article}

Le présent article a pour but d'examiner deux traductions françaises et deux adaptations cinématographiques de Sense and Sensibility, un roman de Jane Austen. Ces traductions et ces adaptations offrent un terrain fécond à qui s'intéresse aux phénomènes de " reconstruction » idéologique des textes sources. Nous appuyant sur une critique littéraire de l'oeuvre dans le contexte de la théologie anglicane néoclassique, nous nous proposons de décrire les modes d'inscription et de neutralisation du texte source. Ceci nous permettra non seulement de démontrer que les opérations de reconstruction effacent la via media anglicane, mais aussi de cerner de près le rapport entre traduction et adaptation cinématographique. 


\title{
Translation, Adaptation, Inscription: Displacing God in Austen's Sense and Sensibility
}

\author{
ALAN J. E. WOLF \\ University of East Anglia, Norwich, UK \\ a.wolf@uea.ac.uk
}

\begin{abstract}
RÉSUMÉ
Le présent article a pour but d'examiner deux traductions françaises et deux adaptations cinématographiques de Sense and Sensibility, un roman de Jane Austen. Ces traductions et ces adaptations offrent un terrain fécond à qui s'intéresse aux phénomènes de «reconstruction» idéologique des textes sources. Nous appuyant sur une critique littéraire de l'œuvre dans le contexte de la théologie anglicane néoclassique, nous nous proposons de décrire les modes d'inscription et de neutralisation du texte source. Ceci nous permettra non seulement de démontrer que les opérations de reconstruction effacent la via media anglicane, mais aussi de cerner de près le rapport entre traduction et adaptation cinématographique.
\end{abstract}

\begin{abstract}
Focusing on a comparative analysis of film adaptations and French translations of Jane Austen's Sense and Sensibility, this article examines the ideological reconstruction of source texts. More precisely, it proposes a way of describing the inscription and displacement of values in Sense and Sensibility based on a reading of the work in the context of Anglican neoclassical theology. This will provide the basis for the claim that the Anglican via media is displaced whilst allowing us further to explore the relationship between adaptation and translation.
\end{abstract}

\section{MOTS-CLÉS/KEYWORDS}

adaptation cinématographique inscription, théologie néoclassique, Anglican, via media film adaptation, inscription, neoclassical theology, Anglican, via media

\section{Introduction}

Discussion in the fields of Translation Studies and film adaptation has been largely dominated by the much debated question of whether renderings are faithful to the original text or not. In translation studies equivalence to the source text is not seen as a desirable end. Toury (1995: 178), for example, in an analysis of Japanese poems translated into English, argues that it is perfectly justifiable to omit some of the characteristic features of Haiku poetry, such as the seventeen syllables, when one is engaged in "literary translation" rather than "source text translation." Likewise, in the field of film adaptation, it has been suggested (McFarlane 1996: 194) that the obsession with the issue of fidelity is stifling the study of adaptation. Fidelity cannot profitably be used as a reliable evaluative tool mainly because what fidelity critics express dissatisfaction with is that "the illusion of reality created by the film does not coincide with [...] the illusion of reality created by the novella" (McFarlane 1996: 164). Indeed, they write as if "their" interpretation of the original text is "fixed" and should prevail over that of the film-maker. 
Although much has already been written (Hervey 1997; Malmkjær 2005; Venuti 2007) on how film makers and translators "inscribe meaning" (Venuti 2008) in their works which differs from that of the source texts, the strategy of displacing the religious aspects of a classical work is much less documented. In the present paper, I draw attention to some of the processes involved in converting Sense and Sensibility to film and to translated text, and hope to gain a better understanding of the kindred relations between adaptation and translation. In particular, the present discussion challenges Stam's view that equivalence is a useful alternative to the notion of fidelity, i.e., a "principled effort of semiotic transposition, with the inevitable losses and gains of any translation" (Stam 2000: 62). Far from being an alternative to fidelity, equivalence is in many ways a related notion and, here, I agree with Paul's (2008) penetrating analysis of the relationship between adaptation and translation as "analogous processes." In the concluding section of this paper I consider the implications of a specific view of equivalence in the context of adaptation and fidelity.

My method here will be to use literary criticism as a basis for analysing two film adaptations and two French translations of the novel. North (1999) points out that this approach may need some defence, but she observes, citing McFarlane (1996), that literary criticism is just one among many contexts within which an adaptation can be analysed. I realise that my approach may appear to be an instance of fidelity criticism, thus privileging the text over the film, but this is not what I intend here. My aim is to show that literary criticism constitutes a legitimate basis for examining how the religious aspects of the novel are treated in the receiving cultures of film adaptation and translation, respectively. ${ }^{1}$ Such an approach has the advantage of making it possible systematically to identify the translated passages for their religious significance. The translations I have selected are (a) the earliest translation of Sense and Sensibility by Isabelle de Montolieu in $1828^{2}$ and (b) the translation by Privat in 1979. ${ }^{3}$ The reason for choosing Montolieu's (1828) Raison et sensibilité ou les deux manières d'aimer is that it is deemed to be responsible for the disheartening misunderstanding of Jane Austen in France as a "sentimentalist and, consequently, as a minor popular author, one of those 'romancières anglaises' usually regarded as outlandish curiosities by French reviewers" (Cossy 2010: 1). This translation was thought, therefore, to provide the ideal opportunity for documenting the inscription of sentimentalism and the displacement of religious content. Jean Privat's (1979) Raison et Sentiments was selected because it was reputed to be "rooted in contemporary French" (Moody 2009: 1) whilst allegedly keeping to "Austen's syntax" (Moody 2009: 1) and Anglo-Saxon lexis. The two translations were also far apart from each other in time, and I started with the assumption that the Privat (1979) translation might include more inscriptions of meaning than the earlier one, in which, as we shall see later, I was mistaken.

The two screen adaptations of Sense and Sensibility I have analysed are those directed by Ang Lee (1995) and John Alexander (2008), respectively. ${ }^{4}$ The Ang Lee adaptation, based on Emma Thompson's screenplay, was released to a generally warm reception, ${ }^{5}$ and included such well-known actors as Emma Thompson (Elinor), Hugh Grant (Edward), Alan Rickman (Colonel Brandon), Kate Winslet (Marianne) and Hugh Laurie (Mr Palmer). By contrast, Alexander's (2008) television serial, adapted by the BBC and written by Andrew Davies, included a less well-known cast, Hattie Morahan (Elinor), Charity Wakefields (Marianne), and Dan Stevens (Edward), and 
received mixed praise from film critics. Sutcliffe (2008), for example, whilst acknowledging the quality of the casting, was critical of the "romantic Sturm und Drang" and the "gratuitous heavy breathing" of the opening scenes. These two adaptations placed themselves in different positions in Jane Austen's work, the later adopting a romantic, possibly more populist stance. ${ }^{6}$ They seemed, therefore, to reveal a sufficiently varied range of inscriptions for my analysis of the relationship between translation and adaptation.

What follows is a brief overview of adaptation and translation in relation to Sense and Sensibility for us to begin to appreciate the inter-relatedness of the phenomena involved. We will then turn our attention to a particular reading of Austen's work, that of Giffin (2002), for whom the novel Sense and Sensibility engages "in a moral discourse" commonplace in the Georgian period in which Austen wrote. The moral discourse referred to here is one which is informed by a Georgian neoclassical Anglican theology, a via media ${ }^{7}$ which is the basis of Austen's Anglicanism.

In this respect, Giffin's (2002) reading of the text is crucially important in that it allows us further to explore how in the process of translating and adapting the text a significant shift occurs from a neoclassical theological context to a displacement of God where romanticism and, paradoxically, rationalism, are allowed to dominate over the Anglican via media.

\section{Film adaptation}

In attempting to formulate a concept of adaptation, Wiltshire (2001) offers a suggestive point of departure. In his view, adaptations of literary classics can be understood as re-readings of source texts. One advantage in this argument, Wiltshire (2001: 5) notes, is that adaptations are seen to bring out into the public arena the distortions which might have been undisclosed in the private reader's "own imaginative process." Venuti (2007: 27), too, citing Stam (2000: 68), observes that film adaptations have been increasingly understood as hermeneutic interpretations of prior material determined by the "cultural situations and historical moments in which they are produced." In other words, film adaptations reconstruct precursor texts both creatively and ideologically. And they can do so in a number of ways.

Because of our hankering for the past, film adaptations can produce nostalgia and are often seen to be "symptomatic of the condition of the national psyche [...] reverting to its past tones under the stress of contemporary economic, political and social crisis" (Gidding 1990: 38). A number of writers on the subject have commented on the essentially conservative nature of adaptation (Lyttle 1996; North 1999; Wiltshire 2001). Lyttle (1996), for instance, claims that the ideology of the novel, no matter what it may be, always succumbs to the conservative ideologies of adaptation. He refers to Ang Lee's (1995) Sense and Sensibility which stressed the vulnerability of women in a patriarchal society but attenuated the message by using visually intoxicating images such as "acres of radiant countryside" and "sundry soft furnishings." North (1999) agrees that "Austen has become a conservative icon in popular culture: a canonical writer whose life and work signify English national heritage." And for Wiltshire (2001: 8), the films only serve to comfort readers in the idea they already have of Austen as "stultifyingly genteel, complicit with patriarchy, a velvet enforcer of convention and conformity." 
Adaptations, however, do not necessarily look back to a rose tinted past. As Whelehan (1999) observes, Austen's novels can be reconstructed from a late $20^{\text {th }}$ century perspective. She refers, for example, to the BBC adaptation of Pride and Prejudice as a sexualisation of Darcy "a clear object of the female gaze" and to the "feminist context" of Ang Lee's Sense and Sensibility (1995).

\section{Translation and Austen}

Translations, like adaptations, are ideologically constructed acts which de-contextualise the original text. It is in this sense that they should be carefully scrutinised, since they "operate as a performative, creating meanings and values that often transform the foreign text beneath an illusionistic transparency, reflecting the interests of the receiving culture" (Venuti 2008: 49).

As far as the French translations of Austen are concerned, it does not take a reader very long to notice how translators felt it necessary to de-contextualise her text in order to reflect the interests of the host culture. As Cossy and Saglia (2005) observe, Austen's novels were deemed to be very English, and translators adapted them so that they suited the taste for sentimentalism prevalent in the French Restoration, thereby suppressing Austen's irony. Central to the concerns of this paper in illustrating the inter-relatedness of translation and adaptation, is Cossy and Saglia's (2005: 170) view that "notions of cultural appropriation and adaptation are [...] critical to address the earliest translations of Austen's novels."

Sense and Sensibility was translated by Isabelle de Montolieu in 1828 as Raison et Sensibilité ou les deux manières d'aimer. Her translation, written in the tradition of the French sentimental novel, "colludes" with Marianne as a "sentimental icon" (Cossy and Saglia 2005: 175). Montolieu inscribes her ideological leanings towards sensibility by means of additions. Willoughby, for example, becomes a respectable widower at the end of the novel and marries Colonel Brandon's ward, generally becoming a wiser man: "je vivrai en philosophe à Haute-Combe entre ma femme et mon enfant” (Austen 1811/1828: 240). Marianne's response: “cette dernière s'enflamma de cette idée et conjura son mari d'y consentir" (Austen 1811/1828: 239) provides a tidy ending to the novel possibly inspired by the editors of the series Bibliotheque Britannique, a group of men led by Auguste Pictet who, in Cossy and Saglia's (2005) words, "dreamed of a well-ordered society united around its middle classes."

Although I will explore the relationship between translation and adaptation further in later sections of this paper, I would like, for now, to elaborate on the controversy surrounding the putative opposition between the two in the context of Translation Studies.

The debate, recently outlined by Bastin (2008: 8), concerns the "theoretical boundaries" between translation and adaptation. In his own discussion of the two concepts, he is keen to observe that serious analyses of the phenomenon perceive the borderline which separates them as "tenuous."

Having identified seven modes of adaptation, he outlines four reasons why translators may feel compelled to resort to it (Bastin 2008: 7): cross-code breakdown (when there is a semantic void in the target language), situational inadequacy (where the context referred to in the source text does not exist in the target culture), genre switching (a change from one genre to another, e.g., from an adult to a child's story) 
and the disruption of the communication process (the need to address a different type of readership). These conditions, he argues, can lead to two major types of adaptation, a local adaptation which is the result of problems at text level, and a global adaptation which is determined by extra-textual factors involving "wide-ranging revisions" (Bastin 2008: 7).

What Bastin (2008: 7) does not explicitly refer to, however, are the ideological constraints under which translators wittingly or unwittingly operate with the subsequent mobilisation of meaning evident in their products (see, for example, Wolf 2009). Indeed, he does not elaborate on the nature of these "wide-ranging revisions" although one may fairly assume that this is one area where the kind of ideological appropriation I observed earlier is most likely to occur. So why not explicitly refer to the role of ideology in translation? Because, amongst other things, it allows for a blurring of the distinction between translation and adaptation. And while Bastin (2008: 8) does admit that the opposition between the two is crucially important, referring, for example, to the "heated debates that have raged over the translation of the Bible," his conclusion that the controversy between adaptation and translation is no more than a "fetishization" (Gambier 1992: 424, cited in Bastin 2008: 8) of source texts such as the Bible, is unhelpful, if not offensive to some.

Lastly, Bastin (2008: 8) justly situates the analysis of the translation/adaptation debate within the relevance theoretic framework of inferential communication (Sperber and Wilson 1986) as others, including myself, have also done (see Wolf 2010). But in order to analyse the mechanisms by which meaning is recovered beyond the traditional code model, it is important that we place the wide array of inferences to which the process of adaptation gives us access under much scrutiny. This Bastin (2008) does not seem very willing to do.

What I will offer here is an analysis of how adaptation, albeit a legitimate translational strategy, is often carried out in the context of ideologically constrained inscriptions of values which go beyond the boundaries of that which is merely said.

\section{Austen's Anglican “via media”}

Before proceeding with an analysis of how adaptations and translations have displaced the religious in Sense and Sensibility, it is important to gain an insight on the subject of Austen's Anglicanism as an expression of neoclassical religious morality.

Several critics (Butler 1975; Leighton 1983; Poovey 1984) have analysed Sense and Sensibility as a didactic novel which exemplifies the contrasting values associated with sense, a valuing of reason, and sensibility, characterised by a reliance on sentimental behaviour. Butler (1975: 189), for example, observes that Marianne stands for "a doctrine of complacency and self-sufficiency which Austen as a Christian deplored." These writings, however, rarely show an interest in what is meant by being a Christian in Georgian England. This is why my attention has been drawn by Giffin's (2002: 6) argument that Austen's novels are "commentaries" on the "moral discourse" of her day.

The moral discourse to which Giffin (2002) refers is informed by a neoclassical Anglican theology. In this context, Austen writes novels which illustrate how collective salvation, which Giffin (2002) calls soteria ${ }^{8}$, can be achieved by her characters through "arriving at a proper understanding of their dependent and interdependent 
social situation or context" (Giffin 2002: 7). It is worthwhile considering here that this understanding of salvation derives from an Old Testament focus on physical preservation rather than on later Christian usage which emphasised moral and spiritual salvation through Jesus Christ (Nobbs 1988). As Giffin (2002: 7) observes, Austen does not question the truth of the other-worldly or Aristotelian sense of soteria but it is the Old Testament understanding of soteria that prevails in the novels, "each novel is directed towards achieving the physical and emotional soteria of its characters and its communities" (Giffin 2002: 7). The soteriology of Austen's novels, then, manifests itself at the levels of both the oikia (household) and the oikonomia (management of the household). ${ }^{9}$ For Austen, the oikonomia of the household is the microcosm of the state and the oikonomia of the parish is the microcosm of the Church (Giffin 2002: 30). The this-worldly basis of Austen's soteriology is very important as it enables us, amongst other things, to be clear about what has sometimes been referred to as her ambiguous attitude to Evangelicalism (Butler 1975: 162). It is very unlikely that Jane Austen would have felt comfortable with the claims of the Evangelical Christians that they are born again through the process of accepting Jesus Christ as their "personal saviour" (Hendershot 2004: 2) for such an insistence on a personal encounter downplays the role of salvation as a means of achieving the physical well-being of communities.

One central theme in the novels is how fallen characters manage disordered oikonomia in their families and by extension their community (Giffin 2002). The Georgian model of oikonomia is inspired by the New Testament model of the Christian household (see St. Paul's $2^{\text {nd }}$ letter to the Colossians) in which wives are enjoined to be subject to their husbands and husbands not to be harsh to their wives. Also familiar to Austen's period of writing would have been the Form of Solemnization of Matrimony (Book of Common Prayer 1662) which asks the bride: "Wilt thou obey [this man], and serve him, love, honour, and keep him, in sickness and in health; and, forsaking all other, keep thee only unto him, so long as ye both shall live?' Indeed, Giffin (2002: 33) adds that the normative model of being a good wife and a good neighbour in the Georgian period also depends on women recognising that a Colonel Brandon is a more suitable husband than a Willoughby.

Furthermore, Austen's novels are concerned with two different types of marriages: secular and clerical marriages. As Giffin (2002: 34) argues, Austen's oikonomia of soteria depends on them since in the "unregulated" capitalism of the Georgian period they have the "potential to affect an entire community for better or for worse in a period of social, economic and moral change." Giffin (2002: 34) further describes this system of welfare of which the chief administrators seem to be the squire and the priest aided by their wives.

Jane Austen's Anglicanism, then, is characterised by a commitment to the conventions, briefly outlined above, of the "reasonable, enlightened via media of the long eighteenth century" (Giffin 2002: 24). Hers is a "mainstream Anglicanism" (Giffin 2002: 62) which steers a middle course between Roman Catholicism and Evangelicalism.

After this brief overview of some of the distinctive features of Anglican neoclassical theology, let us now turn to a discussion of examples taken from the two adaptations and the two translations of Jane Austen's Sense and Sensibility. 


\section{The Sin of Greed}

The novel starts with the description of an offence having been committed: Mr Henry Dashwood, having failed in his duty to provide for his wife and daughters, "recommends to his son," on his deathbed, "the interest of his mother-in-law and sisters." Mr John Dashwood, described ironically as "not ill-disposed" (Austen 1811/2006: $5)^{10}$, is married to a woman who is a "strong caricature of himself," "more narrow minded and selfish" (Austen 1811/2006: 6). Influenced by her argument that in providing handsomely for his half sisters he would effectively "rob his child" (Austen 1811/2006: 9), he resolves not to do more for the widow and sisters than occasional "neighbourly acts" (Austen 1811/2006: 15). This ironic allusion to what is a leitmotif in the New Testament (Romans, chapt. 15) suggests that in biblical terms, Mr John Dashwood is committing a serious sin: he has broken the commandment of honouring his father and mother (Giffin 2002: 66) and has in effect not looked after the widow and the vulnerable. This sin is a reflection of fallen humanity, and it is how differently the characters in the novel respond to it which enables the narrator to set up an opposition between sense and sensibility (Giffin 2002) ${ }^{11}$. In particular, it is Elinor, the eldest daughter and representative of "sense," who entreats her imprudent mother 'to avoid a breach with their brother' (Austen 1811/2006: 7). Such a breach would, in Georgian society, be improper, and lead to familial enmities of which Mrs Dashwood and her family might in the future repent. As Giffin (2002) astutely comments, it is human agency which Anglican theology believes to be the cause of distress, just as it is human kindness which provides Mrs Dashwoood and her daughters with soteria.

The two film adaptations represent this grave sin in similar fashion, though a number of details are treated differently as far as the moral and theological texture of the story is concerned. Both start in medias res and state that the estate cannot be divided between John Dashwood and Mr Henry Dashwood's wife and daughters. Both films omit the reference to John Dashwood's son, Harry, who when he visited the old gentleman had "gained on the affections of his uncle" (Austen 1811/2006: 5) thus causing, albeit unwittingly, the old gentleman's decision to bequeath the estate undivided for his own benefit. In the 2008 adaptation, John Dashwood's son, later becomes a part of Mrs Dashwood's argument for not giving Mrs Dashwood and her daughters an annuity: "Your papa is intent on robbing you." But since the preceding sections of the argument are missing, Mrs Dashwood is made to seem even greedier than in the novel. The 1995 adaptation omits all reference to the boy with the effect of attenuating the "double moral outrage" (Giffin 2002): first, a mere boy manages in a few sporadic visits to an old man to "outweigh all the value of all the attention which, for years, he had received from his niece and her daughters" (Austen 1811/2006: 5) and secondly, he becomes the basis on which his father, John Dashwood, is finally persuaded to do no more for the widow and children than the occasional acts of charity. Inscribed in the 2008 film narrative is the $21^{\text {st }}$ century sin of greed with the portrayal of an overweight boy gorging himself on cake.

Of note, too, is the fact that the mood created from the start of the 2008 adaptation is one where High Church sentimentalism and morbidity prevail over the Anglican via media. The visual context is reminiscent of the Victorian celebration of death (Richardson 1987: 106) with its "funerary etiquette," its abundance of black 
gowns, its horse-drawn hearse and "everything swathed in crape." By contrast, in Georgian times, dying had come to be represented as an "easy transition to a more blessed state" (Porter 1989: 86) and the need for "great public scenes" was not felt, so that funerals were frequently carried out through "private person to person contact" even sometimes excluding clergy. Besides, in attendance at Henry Dashwood's death scene, are the three girls and Mrs Dashwood. Again this serves, no doubt, to heighten the dramatic intensity of the scene. Although it might have been expected that members of the family sat around Mr Dashwood's bed in his last moments, Austen pointedly elided the scene from her novel since, as Collins (1994: 186) observes, she did not expect bereaved people to "wallow" in their distress. In Persuasion, for instance, Austen represented Mrs Musgrove's grief over her son's death as self-indulgence. Nor did she agree with her Evangelical cousin, Edward Cooper, who was likely to send letters of "cruel comfort" to her brother, rejoicing at death as a welcome passage to a better world (Austen (1808), cited in: Le Faye 1995: 148). ${ }^{12}$ Instead, Austen encourages a typical Anglican via media. After a period when grief cannot be moderated, a sense of duty, "the most acceptable proof of love to the spirit of the [...] departed [...]," must prevail (Austen (1808), cited in: Le Faye 1995: 147). This sense of duty expresses itself through tranquil resignation.

We have observed that the relationship between adaptation and translation can be made fruitfully in the context of how an ideology is transferred or not in the target text. Looking at the French translations of Sense and Sensibility, it is of particular interest to see that Montolieu's (1828) traduction libre resorts to the same inscriptions as the 2008 film adaptation, albeit 180 years earlier, and has the whole family in attendance at Henry Dashwood's dying moments: "il expira doucement dans les bras de sa femme et de sa fille, au désespoir de sa perte” (Austen 1811/1828: 4, translated by Montolieu).

That the interpretative directions adopted by the translations and the adaptations are similar is not surprising. In their inscribing of sentimentalism, both Montolieu (1828) and Alexander (2008) have not only detached the original text from its neoclassical context, but have re-contextualised it to conform to the prevailing fashions of their age, e.g., the contemporary taste for Victorian-style funerals. Venuti (2007: 30) is helpful here in reminding us that translators do this in terms that are "intelligible to receptors situating [the source text] in different patterns of language use, in different literary traditions [...] and often in a different historical moment." In film adaptations, he notes (Venuti 2007: 30), the recontextualization can be more extensive because of the "shift to a [...] multi-dimensional medium [...] inflected by different styles of acting, directing and studio production." And one may add, cynically, to his list, commercial interest and box office success.

Venuti (2007: 31) introduces the category of the "interpretant" here which helps us to understand the mechanisms by which translators and film directors inscribe an interpretation, thereby guiding the decontextualising and recontextualising of the source text. An interpretation is inscribed "which mediates between the source language and culture [...] and the translating language and receiving culture" (Venuti 2007: 31).

This category, which Venuti borrows from Iampolski’s (1998) writings on intertextuality in films, is itself derived from Charles Sanders Peirce's theory of the sign. Although Venuti (2007) elaborates on the notion in an illuminating way, he does not 
himself make any reference to Peirce and we gain a more secure understanding of the notion if we turn to the person who introduced it first.

In Peirce (see Buchler 1956: 99), the sign or representamen is "something which stands to somebody in some respect or capacity." The sign then "creates in the mind of that person an equivalent sign, or perhaps a more developed sign." The sign which it creates, Peirce (see Buchler 1956: 99) calls "the interpretant of the first sign." Peirce (see Buchler 1956: 99) links the interpretant to the sphere of pure rhetoric whose task it is "to ascertain the laws by which in every scientific intelligence one sign gives birth to another sign, and especially one thought brings forth another." For Peirce then, the interpretant is a secondary sign which is the basis for the creation of meaning in the human mind. To illustrate this, Peirce (1866, cited in: Fisch 1982: 466) gives the example of the word homme which to a Frenchman stands for man. To be more precise, he argues, we must say that it stands for man to a Frenchman's mind or memory. But, he asks (1866, cited in: Fisch 1982: 466): "what remembrance?." "Plainly," he concludes, "the one which is a mental equivalent of the word homme - in short its interpretant."

The notion of the interpretant has been elaborated on and found to be a crucially important notion in the field of adaptation (Iampolski 1998; Venuti 2007). For Iampolski (1998: 43), the interpretant is a "third text" which enables us to relate the film with its intertext, that is, the precursor text present within it. The interpretant is important, Iampolski (1998: 43) observes, in that it allows us to do away with the notions of borrowing and fidelity by focussing on the "creation of meaning with all its displacements and transformations."

Such an understanding of the interpretant, however, fails "to clarify," argues Venuti (2007: 31), "the interpretation that the film inscribes in the intertext." Indeed, Iampolski's (1998: 57) notion of the interpretant as a term to be understood very broadly to mean a whole field of artistic creation, a kind of "superarchitext" is so all-embracing that it "limits the explanatory power of the term" (Venuti 2007: 31).

I want to claim here that it is Venuti's elaboration of the interpretant which is a centrally important category for studying the relationship between translation and adaptation. This is because Venuti (2007: 33) refers to it as that which "enable(s) the film to inscribe an interpretation by mediating between its prior materials, on the one hand, and the medium and its conditions of production, on the other - by providing, in other words, a method of selecting those materials and transforming them into the adaptation through the multimedial choices made by the filmmakers."

In adaptation as in translation, an interpretant can be either formal if it consists of establishing a mediating relation at semantic or syntactic level, i.e., a "structural correspondence between the adapted materials and the film" (Venuti 2007: 33) or thematic if it inscribes values and particular beliefs into the receiving text. Clearly, thematic interpretants are more likely to occur in intersemiotic adaptations such as films, and Venuti's (2007: 35) example of Franco Zeffirelli's 1968 adaptation of Shakespeare's Romeo and Juliet is a good illustration of this process: here we have two thematic interpretants, one which inscribes an "idealization of the heterosexual love between the two leads" (Venuti 2007: 35) and another which focuses on the homoerotic relationships among the male characters.

The crucially important point raised by Venuti (2007: 28) is that while fidelity criticism has a tendency to privilege the original text over the adaptation, an approach 
based on formal and thematic interpretants can be seen to treat the phenomenon of inscription so objectively as to prevent a critical discussion of the translating and adapting process. Indeed, it is not only necessary to pay attention to interpretants, but also to be critical of them, especially when they are imposed on reconstructed texts by ephemeral fashions and dominant ideologies. Such inscriptions may be obvious in Montolieu's case because we judge her work with the benefit of hindsight. Although our appreciation of contemporary adaptations is clouded by lack of distance, the inscriptions are revealed when we compare them to those imposed on texts more than a century ago.

\section{6. "Sense" and "Sensibility" in translation}

The moral outrage perpetrated at the beginning of the novel gives the narrator the opportunity to contrast the different characters in terms of how they respond to the event (Giffin 2002: 65). Elinor is said to "possess a strength of understanding" which "qualifies her" to be the counsellor of her mother whose "eagerness of mind [...] generally [...] led to imprudence" (Austen 1811/2006: 7).

In the Montolieu (1828) and Privat (1979) translations, the character of Elinor is portrayed as displaying qualities of enlightened rationalism. Montolieu (Austen 1811/1828: 4) presents Elinor as the elder sister, who "possédait une force d'esprit, une raison éclairée, un jugement prompt et sûr." Note here the phrase raison éclairée which echoes allusively le Siècle des lumières. ${ }^{13}$ Rather than possessing a "strength of understanding" (Austen 1811/2006: 7), she is described by Privat (1979: 10) as "douée d'une force d'intelligence [...] qui faisait d'elle [...] le conseiller habituel de sa mère." The lexical items intelligence and conseiller in French both emphasise the sense of Elinor standing in the capacity of a quasi official adviser to her mother, rather than that of a counsellor. The translators' formal interpretants contribute to a portrait being drawn of Elinor as a gifted individual, ruled by scientific, possibly godless, reason. These semantic slippages have been responsible for a long-standing argument over the French translations of Jane Austen. Sense is frequently inscribed as raison or esprit, which, as Bour (2007: 20) observes, commenting on Montolieu's translation, is more "a principle of intellectual life" than a "sane and practical attitude to situations" (Collins English Dictionary 2009). ${ }^{14}$

This suggests that translations of Sense and Sensibility into French encounter two interpretative obstacles, one to do with the rendering of sense and the other with the translation of sensibility.

Sense is identified with intellectual rationality and is translated as raison or esprit which lends the character of Elinor its unwarranted unbending coldness. Raison here has nothing of the quality which, on the basis of an Anglican via media, furthers the community's soteria and enhances the values of oikonomia. For Sense, conceived by Austen, is what Collins (1994: 188) describes as a middle way between the "rationalism of the Deists" and the "extreme irrationalism of the evangelicals."15 Indeed, there is evidence that the Austenian position owes much to her favourite preacher, Thomas Sherlock, ${ }^{16}$ whose sermons she read frequently. In those, he equated the reasonable with the rational, arguing that it was reasonable to believe in a Creator whose universe bore the stamp of reason, order and harmony (cited in Knox 1791: 266). Jane Austen is not likely to have favoured Evangelical attempts to downplay the 
role of scholarship since she came from a family of divines whose traditional Anglican approach was to gain a better understanding of scriptures informed by the serious study of the ancient languages. Indeed, Jane Austen rejoices at the report that Henry Walter" "was considered to be the best Classick in the University" (Le Faye 1995: 199).

When we come to the word sensibility, we see it rendered as sentiment (feeling), and especially so by Montolieu, to imply a "defining characteristic of a truly noble human being" (Bour 2007: 20) rather than an excessive belief in the tenets of romanticism. When an opportunity arises for an ironical attitude to sensibility, the Montolieu translation misses it. In the passage where the girls are about to set off to London with Mrs Jennings, for example, Austen tells us that "Elinor was the only one of the three who seemed to consider the separation as anything short of eternal" (Austen 1811/2006: 180). In Montolieu, the subtle ironical tones conveyed by the narrator's echoic mention of Mrs Jennings' and Marianne's rhetorical exaggerations ${ }^{18}$ are replaced by a ponderous inscription totally lacking in irony: "Elinor fut la seule qui, par son courage, adoucit le chagrin de la séparation en répétant combien elle serait courte et en parlant de l'époque du retour" (Austen 1811/1928: 22, translated by Montolieu).

As a result, sense and sensibility in the French translations become almost mutually exclusive concepts. It is no surprise then that the critical reviewers of the recent films in France espouse such a facile dichotomy (see Bour 2007: 70), seeing in Marianne le cour (the heart) and in Elinor, the embodiment of la raison or that they resort to a simplified view of English fiction by female authors as being about "English old ladies." This is precisely what is being argued here, namely that subtle semantic nuances and culturally fragmented prisms can influence interpretative and translational strategies over many years, without a minority interpretation being able to gain recognition.

\section{Edward: French "intellectuel" and romantic hero?}

Another character deserves our attention, that of Edward Ferrars. This is because he is described in the novel as a man of sound judgement and represents, in theological terms, the perfect neo-Georgian clergyman who knows when it is pastorally appropriate to express a personal opinion (Giffin 2002). As Elinor comments, (Austen 1811/2006: 23): "I venture to pronounce that his mind is well-informed."

The French translations have a somewhat erratic approach in their presentation of Edward, mainly because of the way in which the terms sense and goodness are translated. Whilst the original text conveys the harmonious Anglican combination of pastoral usefulness and goodness in Edward's character, both translations tend to emphasise his intelligence and his capacity for rational judgement. Where Elinor refers to his goodness: "Of his sense and goodness" [...] "no one can, I think, be in doubt" (Austen 1811/2006: 23), the Montolieu translation offers the formal interpretant: "il est impossible, dit Elinor, lorsqu'on connaît Edward, lorsqu'on l'a entendu parler, de douter un instant de son jugement droit et de sa bonté" (Austen 1811/1828: 34, translated by Montolieu). Although bonté is rightly retained here, jugement droit implies integrity rather than good sense. The later Privat (1979) translation goes even further in highlighting the intellectual and principled nature of Edward's character: 
"Pour son intelligence [sense] et ses principes [goodness] [...] il est impossible de les mettre en doute" (Austen 1811/1979: 23, translated by Privat). Where Elinor finds Edward's mind "well-informed," implying that he is a well-rounded though not a necessarily academically-minded person (Austen 1811/2006: 23), the French (1979) translation uses the phrase "son esprit est fort cultivé" (Austen 1811/1979: 24), thereby emphasising Edwards' enjoyment of intellectual pursuits.

When Marianne expresses her opinion of Edward, she, like Elinor, uses the terms goodness and sense: [...] "I have the highest opinion in the world of his goodness and sense" (Austen 1811/2006: 23). The Privat (1979) translation here renders goodness as droiture which orients Edward's character towards incorruptibility, a legalistic rather than soteriological understanding of goodness. The earlier Montolieu (1828) translation fares a little better, although inexplicably, the word raison (reason) is added: "mais je vous assure que j'ai la plus haute opinion de sa bonté, de sa raison, de son bon sens" (Austen1811/1828: 33, translated by Montolieu),

It is difficult to account for this focus on Edward's intellectual rationalism and bloodless integrity except in terms of a lack of identification on the translators' part with what an Anglican clergyman is meant to represent in Jane Austen's novels. And where better to find a coherent articulation of Anglican ministry than in Edmund Bertram's eulogy of priesthood in Mansfield Park? It is in his ministry of presence that "a good clergyman will be useful in his parish" rather than in "fine preaching." A clergyman, Edmund continues, "has the charge of all that is of the first importance to mankind, individually or collectively considered, temporally and eternally [...] the guardianship of religion and morals, and consequently of the manners which result from their influence" (Austen 1814/1994: 94). ${ }^{19}$

By manners, here, Edmund does not mean that clergymen are the "arbiters of good breeding." The manners he speaks of "might rather be called conduct, perhaps, the result of good principles; the effect, in short, of those doctrines which it is their duty to teach and recommend" (Austen 1814/1994: 95) ${ }^{20}$. Those manners are also allied to a sense of what is useful to the community. As Letter 13 makes clear, the clergy ministered in a variety of ways, giving out home-made remedies, and helping to place their parishioners in employment (Le Faye 1995: 24).

Closely allied to the sense of what is useful to the community is Edward's neoclassical - as opposed to a romantic - sense of aesthetic (Giffin 2002: 77). In a passage where he returns from a walk in Barton, Edward interrupts Marianne's romantic praise of the neighbourhood, much to her amazement, by saying, with a note of irony:

You must not inquire too far, Marianne; remember I have no knowledge in the picturesque, and I shall offend you by my ignorance [...] I shall call hills steep, which ought to be bold; surfaces strange and uncouth, which ought to be irregular and rugged; and distant objects out of sight, which ought to be indistinct through the soft medium of a hazy atmosphere. (Austen 1811/2006: 112)

Edward's observations, argues Giffin (2002: 77), are a reflection of his disagreement with Marianne's sensibility of disorder. Edward's sensibility is one which combines beauty with a sense of what is useful and is informed by the Christian notion of effective stewardship. The Bible enjoins us to be stewards of the earth (Genesis 1), and to be cautious, like the wise virgins making sure they had enough oil for their lamps before the return of the bridegroom (Matthew 25). Thus, Edward is likened to those who are mindful of others and, would, like Austen (Collins 1994: 175) have 
been critical of heedless landowners. And so Edward is not fond of "crooked, twisted, blasted trees" or of "ruined, tattered cottages" (Austen 1811/2006: 113), however sublime and picturesque in a Mariannesque conception of the world they may be, simply because they imply social decay, disorder and bad husbandry.

The Montolieu translation, through a number of omissions, not only tends to accentuate the differences in opinion between Marianne and Edward, but does not give the latter sufficient space to give a coherent account of his opinions. The passage where Marianne admits that "admiration of landscape scenery is become mere jargon" (Austen 1811/2006: 112) thus showing some kind of agreement with Edward's position, is missing (Austen 1811/1828: 176). Omitted too is Edward's reference to "a troop of tidy, happy villagers" which, he finds, please him better than "the finest banditti in the world" (Austen 1811/2006: 113). Here Edward, by introducing the image of happy villagers, is given the opportunity to develop his argument that they are a reflection of sound, Christian, and effective stewardship. There is even a sense in which he wins the argument: "Marianne looked with amazement at Edward, with compassion at her sister" and "remained thoughtfully silent" (Austen 1811/2006: 113). No such silent contemplation in Montolieu where Marianne looks at Edward scornfully: "Marianne regarda Edward avec mépris" (Austen 1811/1828: 176, translated by Montolieu). The French 1979 translation does attempt to convey some of Edward's ideals of beauty but because of a lack of familiarity with these concepts, a number of lexical choices tend to obscure the characteristic neoclassical relationship between beauty and utility. The problems talked about remain at an implicit level and are probably inaccessible to the reader. Whereas the valley looks comfortable and snug (Austen 1811/2006: 112) in English, thus conveying a general sense of beauty united with utility, the valley is cachée (hidden) in the French translation (Austen 1811/1979: 99) and the rather infrequent word utilité is used. Indeed, the term is not likely to echo a philosophy of utilitarianism in France. The woods which are full of fine timber (Austen 1811/2006: 112) are, in the translation, planted with de beaux arbres, i.e., decorative rather than useful trees. The film adaptations have cast Hugh Grant (1995) and Dan Stevens (2008) as Edward and in both cases, the character is invested with the handsome looks of romantic leads. Both adaptations omit the thematic interpretant of Edward's visit to Barton. It is the 2008 adaptation of Edward (episode, 2, scenes $4 / 7,5 / 7)$, however, which most explicitly injects a note of sensuality into the narrative.

Jane Austen's concerns about the varied characters' responses to the picturesque, ideas of goodness and the usefulness of clergymen to their community are not contemporary concerns. Such concerns would appear to be distinctly counter-cultural and unlikely to attract contemporary audiences. Accordingly, these thematic interpretants are displaced. Instead, what receives particular attention is the sensual, romantic hero, moodily chopping wood in open-necked billowing white shirt.

\section{Love making and a sense of community}

I have argued here that translational strategies are demonstrably similar to those used in the adaptation of literary classics. Like the producers of mass entertainment, Montolieu yielded to the fashions of her age. One last example will serve to illustrate the way in which translations and adaptations reveal the constraints of the times in which they are produced. Edward announces his freedom from Lucy Steele and, as 
Elinor runs out of the room bursting into tears of joy, he falls into a reverie and without saying a word, quits the room and walks out towards the village. Jane Austen uses this departure to give Edward some time to reflect on how he is going to propose to Elinor for it would be too presumptuous to assume that she would accept him. With characteristic Austenian restraint, the manner in which Edward is received is not narrated. We are told that three hours after his arrival, he had "secured his lady" and "engaged her mother's consent" (Austen 1811/2006: 409). At the table to which they subsequently sit down he is given the opportunity to confess the error of his boyish attachment to Lucy Steele.

By contrast, in Montolieu's ending, the tendencies of the sentimental exhibitionist are manifest. Far be it from her to miss an opportunity of telling the manner in which Edward was received. Indeed, he is portrayed as kneeling down in the living room at the feet of Mrs Dashwood and Elinor who cry for joy in each other's arms: "ils passèrent dans la salle à manger où la mère et la fille pleuraient de joie dans les bras l'une de l'autre. 'O ma mère! O ma Elinor!' dit Edward à genoux devant elles. Pendant longtemps il n'y eut entre eux que des acclamations de bonheur et de joie" (Austen 1811/1828: 197, translated by Montolieu). The film adaptations resort to similar thematic interpretants. In the 1995 Ang Lee adaptation, Elinor breaks into sobbing only a little short of hysterics, the family go out into the garden and Edward is left alone with her. The strains of the film score start sweetly to underline the mounting romantic effect of Edward's proposal. The 2008 version, albeit less infused with the marks of sentiment, has Elinor in moderately restrained tears running out of the room to be joined there by Edward who proposes to her. Again both are left on their own in mutual romantic adoration.

What is striking about the film adaptations is the fact that the proposal takes place between two individuals rather than within the context of the family as it does in both Montolieu and Austen. This suggests that a shift has occurred culturally in our understanding of marriage. As Giffin (2002: 34) noted, Austen's novels are concerned with marriages because in an unstable period of capitalist economic change, they have the potential to provide much needed soteria to their community. Marriage is part of building a sense of community. Such ideas were clearly far from the minds of contemporary producers and audiences for whom marriage signifies an exclusive partnership of two romantically involved individuals who are expected to isolate themselves from the society of others, incidentally, not unlike Willoughby and Marianne, the victims of sensibility.

\section{Conclusion}

The purpose of this paper was to explore the reconstruction of translated and adapted texts. Over the course of the analysis, we saw how they reflected the cultural obsessions, ambivalences and equivocations of the age in which they were produced. It is in this sense that the processes of adaptation and translation can be seen to "share the same theoretical concerns" (Paul 2008: 163), especially when they are framed in the context of a hermeneutic approach rather than that of fidelity criticism. It is in this sense, too, that Venuti (2007: 42) refers to hermeneutic criticism as "interrogative, exposing the cultural and social conditions [...] of the translation or adaptation that has processed them." 
Keeping this thematic focus in mind, I questioned the impressionistic fluency of the works and documented the way in which notions which were commonplace in neoclassical theology were displaced as a result of translation and adaptation. In particular, I felt it incumbent upon me to lay bare, in a way that may be countercultural, the values inscribed in their midst: High Church Victorian sentiment, the cult of beauty, and individual sensual gratification. By contrast, the dangers of sensibility and individualism are strongly emphasised by the via media of neoclassical theology, and Jane Austen in particular has a constant interest in portraying the community as the privileged site of salvation.

It is important to bear in mind, however, that whilst exposing the social conditions that create translations and adaptations, the critics, and here I include myself, can neither unduly privilege the prior text, nor, as Venuti (2007: 43) observes, put themselves "beyond interrogation."

\section{NOTES}

1. A similar approach has been used fruitfully by Venuti (2008) who, in a recent article, explored the influence of twentieth century Baudelairean literary criticism on translation strategies.

2. Austen, Jane (1811/1828): Raison et sensibilité ou les deux manières d'aimer. (Translated by Isabelle De Montolieu) Paris: Arthus Bertrand.

3. Austen, Jane (1811/1979): Raison et Sentiments. (Translated by Jean Privat) Paris: Christian Bourgois.

4. Sense and Sensibility (1995): Directed by Ang LeE. Culver City: Columbia Pictures. Sense and Sensibility (2008): Directed by John Alexander. London: BBC.

5. In the San Francisco Chronicles, Shulgasser (1995) opines, "Unlike so many other movies of literary provenance, it is clear from the start that this one is going to be entertainment, not homework. Chinese director Ang Lee serves up this sweetmeat without fuss, without the super-seriousness of filmmakers awed by their literary material."

6. The director, John Alexander, acknowledged in an interview with the BBC (consult the following link for the interview: <http://www.bbc.co.uk/drama/senseandsensibility/>, visited on 25 June 2010) that he had focused on the youth of the characters, giving the production a more adolescent feel than previous adaptations. He had also stressed the "elemental" nature of the series by locating Mrs Dashwood's cottage on an isolated windswept part of the coast.

7. "V]ia media ('middle way')" is the phrase used by Giffin (2002: 24) to refer to mainstream Anglicanism. More details will be provided about the Anglican via media in the following sections.

8. Giffin (2002: 6) cites Nobbs (1988) to explain the meaning of soteria which represents "wholeness" and "preservation from disease," then by extension in Christian usage "the salvation offered in Christ."

9. See: Newman, Barclay (1983): A Concise Greek-English Dictionary of the New Testament. London: United Bible Societies.

10. Austen, Jane (1811/2006): Sense and Sensibility. In: Edward Copeland, ed. The Cambridge Edition of the Works of Jane Austen. Cambridge: Cambridge University Press.

11. The prayers composed by Jane Austen (from Minor Works, Chapman 1954: 453-457) also include references to orphans and widows: "...heartily do we pray [...] for the comfort \& protection of the orphan and widow." Chapman, Robert, ed. (1954): The Works of Jane Austen, VI, Minor Works. London: Oxford University Press.

12. Le FAYE, Deirdre, ed. (1995): Jane Austen's Letters. Oxford: Oxford University Press.

13. I use the French phrase Siècle des lumières for Enlightenment here to show the relationship between lumières (light) and éclairer (to light).

14. See Collins English Dictionary (2009): London: HarperCollins, visited on 20 June 2010, <http:// www.collinsdictionary.com>.

15. The Evangelicals opposed the identification of reasonableness with the rational as this was seen to diminish the "mysterious power of God" (Collins 1994: 189).

16. Born in London in 1677 and educated at Eton College and St Catherine's College (Cambridge), Thomas Sherlock was an English churchman and theologian, known for his eloquent opposition 
to the Jacobite rising and his prominent part in the Bangorian controversy (see Oxford Dictionary National Biography (2011) Oxford: Oxford University Press, visited on 28 September 2011, http:// www.oxforddnb.com/).

17. Henry Walter was a younger cousin of Jane Austen (Le Faye 1995: 402, note 12).

18. See Sperber and Wilson's (1986) understanding of the trope of irony as the case of a speaker echoing another through 'mentioning' the propositional content of a preceding phrase whilst distancing himself/herself from it.

19. Austen, Jane (1814/1994): Mansfield Park. London: Penguin Classics.

20. It is important to note that there are echoes here of the "form and manner of Ordering of Priests" in The Book of Common Prayer where deacons are asked by their bishop whether they will "give their faithful diligence always so to minister the doctrine and sacraments."

\section{REFERENCES}

Bastin, Georges (2008): Adaptation. In: Mona Baker and Kirsten MalmkjÆr, eds. The Routledge Encyclopaedia of Translation Studies. London/New York: Routledge, 5-8.

Bour, Isabelle (2007): The Reception of Jane Austen's Novels in France and Switzerland: The Early Years, 1813-1829; The Reception of Jane Austen in France: The Later Nineteenth Century, 1830-1900; The Reception of Jane Austen in France in the Modern Period, 19012004: Recognition at Last? In: Anthony Mandal and Brian Southam, eds. Reception of Jane Austen in Europe. London: Continuum International Publishing, 12-33; 34-54; 54-74.

Buchler, Justus (1956): The Philosophy of Peirce: Selected Writings. London: Routledge/Kegan Paul.

Butler, Marilyn (1975): Jane Austen and the War of Ideas. Oxford: Clarendon Press.

Collins, Irene (1994): Jane Austen and the Clergy. London: The Hambledon Press.

Cossy, Valérie and Saglia, Diego (2005): Translations. In: Janet TodD, ed. Jane Austen in Context. Cambridge: Cambridge University Press, 169-181.

Cossy, Valérie (2010): Why Austen cannot be a "classique" in French: New Directions in the French Reception of Austen. Persuasions on-line. 30(0.2):4p. Visited on 24 June 2010, $<$ http://www.jasna.org/persuasions/on-line/vol30no2/cossy.html>

Fisch, Max H., ed. (1982) Writings of Charles S. Peirce: A Chronological Edition. Vol. 1. Bloomington: Indiana University Press.

Gidding, Robert (1990): Screening the Novel. New York: St Martin's Press.

Giffin, Michael (2002): Jane Austen and Religion. New York: Palgrave Macmillan.

Hendershot, Heather (2004): Shaking the World for Jesus: Media and Conservative Evangelical Culture. Chicago/London: The University of Chicago Press.

Hervey, Sandor (1997): Ideology and strategy in translating children's literature. Forum for Modern Languages Studies. 33(1):60-71.

IAmpolski, Mikhail (1998): The Memory of Tiresias: Intertextuality and Film. (Translated by Harsha RAm) Berkeley: University of California Press.

Knox, Vicesimus, ed. (1791): Family lectures, or domestic Divinity: being a copious collection of Sermons. London: C. Dilly.

Leighton, Angela (1983): Sense and silences. In: Janet Todd, ed. Jane Austen: New Perspectives: Women and Literature. New York: Holmes and Meier Publishers, 128-141.

Lyttle, John (26 August 1996): All dressed up for the movies. The Independent Newpaper. Visited on 24 June 2010, <http://www.independent.co.uk/news/all-dressed-up-for-themovies-1311537.html>.

McFarlane, Brian (26 August 1996): Novel to Film: An Introduction to the Theory of Adaptation. Clarendon: Oxford.

MaLmкjÆR, Kirsten (2005): Linguistics and the Language of Translation. Edinburgh: Edinburgh University Press.

Moody, Ellen (2009): Jane Austen in French. Ekleksographia Wave two: translation special. Visited on 10 January 2009, <http://ekleksographia.ahadadabooks.com/ballardini/authors/ ellen_moody_reviews.html>. 
Noвbs, Alanna (1988): The Idea of Salvation: the transition to Christianity as seen in some early papyri. In: The Idea of Salvation, Prudentia Supplement, 59-63.

NorTh, Julian (1999): Radical Austen, conservative Austen: Sense and Sensibility from Text to Screen. In: Deborah Cartmell and Whelehan Imelda, eds. Adaptations: From Text to Screen, Screen to Text. London: Routledge, 38-50.

PAUL, Joanna (2008): Homer and cinema: translation and adaptation in Le Mépris. In: Alexandra Lianeri and Vanda Zajko, eds. Translation and the Classic. Oxford: Oxford University Press, 148-167.

Poovey, Mary (1984): The Proper Lady and the Woman Writer. Chicago: The University of Chicago Press.

Porter, Roy (1989): Patient's progress: doctors and doctoring in eighteenth-century England. Oxford: Polity.

Richardson, Ruth (1987): Death, Dissection and the Destitute. London: Routledge/Kegan Paul. Sherlock, Thomas (1739): A Sermon Preached before the Lord Mayor. London: J+J Pemberton. Shulgasser, Barbara (13 December 1995): A Austenesque, Thompsonesque experience. The San Francisco Chronicle. Visited on 24 June 2010, <http://www.sfgate.com/cgi-bin/article. cgi?f=/e/a/1995/ 12/13/STYLE2770.dtl>.

Sperber, Dan and Wilson, Deirdre (1986): Relevance: Communication and Cognition. Oxford: Blackwell.

Stam, Robert (2000): Beyond fidelity: the dialogics of adaptation. In: John Naremore, ed. Film Adaptation. New Brunswick: Rutgers University Press, 54-76.

Sutcliffe, Thomas (2 January 2008): Give me plain Jane not soft porn. The Independent. Visited on 24 June 2010, <http://www.independent.co.uk/arts-entertainment/tv/reviews/lastnights-tv-give-me-plain-jane-not-soft-porn-767683.html>.

Toury, Gideon (1995): Descriptive Translation Studies and Beyond. Amsterdam/Philadelphia: John Benjamins.

Venuti, Lawrence (2007): Adaptation, Translation, Critique. Journal of Visual Culture. 6(25):25-43.

Venuti, Lawrence (2008): Translation, Interpretation, Canon Formation. In: Alexandra Lianeri and Vanda Zajко, eds. Translation and the Classic. Oxford: Oxford University Press, 27-51.

Whelehan, Imelda (1999): Adaptations: the contemporary dilemma. In: Deborah CarTmell and Imelda Whelehan, eds. Adaptations: From Text to Screen, Screen to Text. London: Routledge, 3-20.

Wiltshire, John (2001): Recreating Jane Austen. Cambridge: Cambridge University Press.

WoLf, Alain (2009): Mobilizing meaning?: religious symbolism in film adaptations of C. S. Lewis's The Lion, the Witch and the Wardrobe. Journal of Adaptation in Film and Performance. 2(3):239-254.

Wolf, Alain (2010): Inferential meaning in Drama Translation: the role of implicature in the staging process of Anouilh's Antigone. In: Roger Baines, Cristina MARINETTI and Manuella Perteghella, eds. Staging and Performing Translation Text and Theatre Practice. London: Palgrave Macmillan, 87-104. 